\title{
An Investigation on Reproductive Performance, Health Management and Marketing System of Native Sheep in Selected Areas of Bangladesh
}

\author{
Md. Ruhul Amin 1, *, Md. Ershaduzzaman ${ }^{1,2}$ \\ ${ }^{1}$ Conservation and Improvement of Native Sheep through Community and Commercial Farming Project (Component- A, Research $2^{\text {nd }}$ \\ Phase), Bangladesh Livestock Research Institute, Dhaka, Bangladesh \\ ${ }^{2}$ Socioeconomic Research Division, Bangladesh Livestock Research Institute, Dhaka, Bangladesh
}

Email address:

ruhulaminbau@yahoo.com (Md. R. Amin)

*Corresponding author

\section{To cite this article:}

Md. Ruhul Amin, Md. Ershaduzzaman. An Investigation on Reproductive Performance, Health Management and Marketing System of Native Sheep in Selected Areas of Bangladesh. International Journal of Animal Science and Technology. Vol. 4, No. 4, 2020 , pp. $98-103$. doi: $10.11648 /$ j.jjast.20200404.15

Received: November 10, 2020; Accepted: November 21, 2020; Published: December 31, 2020

\begin{abstract}
The present research was conducted to assess the reproductive performance, health management, and marketing system of native sheep in selected areas of Bangladesh. The data was collected from selected 11 Upazilas of 6 districts in Bangladesh. A pre-tested interview schedule was used to collect data from 1768 sheep rearing farmers by using a simple random sampling technique and analyzed descriptively. The study denoted that the age at $1^{\text {st }}$ heat or puberty was $7.01 \pm 0.03$ months. However, the age at $1^{\text {st }}$ lambing was found $12.65 \pm 0.03$ months irrespective of areas. The litter size was found $1.93 \pm 0.01$ and the highest was in Balagonj $(2.17 \pm 0.04)$ Upazila. Moreover, the average birth weight was $0.94 \pm 0.01 \mathrm{~kg}$ and the highest was in Companygonj (1.76 $\pm 0.04 \mathrm{~kg})$ followed by Subornochar $(1.63 \pm 0.18 \mathrm{~kg})$ Upazila. The service per conception rate was $1.10 \pm 0.01$. Most of the farmers $(60.18 \%)$ were used own ram $100 \%$ of farmers were used natural breeding for breeding practice. The sheep rearing farmers in the study areas were found moderately aware of different neo-natal nourishment practices. However, only $6.39 \%$ of farmers in different study areas found dipping of their sheep. The sheep mostly affected by pneumonia $(43.72 \%)$, diarrhea $(40.33 \%)$, alopecia $(28.51 \%)$, bloat $(22.79 \%)$, and parasitic infection $(15.55 \%)$ found in the study areas. The dog bite $(15.55 \%)$ was found a major problem in native sheep rearing irrespective of the study areas. Only $28.51 \%$ and $12.56 \%$ of farmers were used anthelmintic and vaccine respectively. Most of the farmers sell their sheep in the hat/Bazar ( $82.75 \%)$ and $60.46 \%$ of farmers sell sheep to paiker or bapari followed by the butcher $(22.33 \%)$. Furthermore, most of the farmers (82.28\%) fixed value for the sheep on the basis of eye estimation. There was no record of wool selling irrespective of study areas. Lack of organized and structured marketing system found in the study areas. Emphasis should be given to the sustainable improvement of native sheep and marketing systems to improve the livelihoods of rural poor farmers in Bangladesh.
\end{abstract}

Keywords: Native Sheep, Reproductive Performance, Neo-natal Nourishment, Deworming, Disease, Marketing

\section{Introduction}

The small ruminants, especially native sheep are very potential for the production of meat in Bangladesh. The native sheep (Ovis aries) of Bangladesh originated from the wild Urial (Ovis Orientalis Vignei) of Asia. In the country, most sheep are of indigenous types which reared in Barind, Jamuna basin, and Coastal areas [1]. The traditional rearing system causes reduced meat production and poor reproductive performance, which causes economic losses of the sheep farmers [2]. Despite the productive performance due to several technical (genotype, feeding, and health management), institutional, environmental and infrastructural constraints indigenous sheep breeds have great potential to contribute more to the smallholder who has low-input, croplivestock, and pastoral production systems [3]. However, lack 
of technical knowledge about neo-natal nourishment, breeding management, health care management the productive and reproductive performances of native sheep remain low. Moreover, many emerging infectious diseases are spreading over large areas and cause an economic loss of sheep farmers [4]. The reproductive performance, health management practices, and sheep health status need to be investigated and the information is essential to safeguard to prevent potential zoonotic diseases, improve reproductive performance, and support further decision-making [5]. Furthermore, the constraints of sheep marketing are lack of market information, lower price; lack of organized and structured markets [6]. In Bangladesh, inclusive research work related to neo-natal nourishment and marketing of native sheep was not conducted. Hence, considering these facts the aim of this work was, therefore, to evaluate the reproductive performance and health management system along with the marketing system of native sheep at the field level which may contribute to improving reproductive performance, health management, and marketing system of native sheep in Bangladesh.

\section{Methodology}

\subsection{Selection of the Study Area}

The present work was conducted following the logical research methodology. At first, the problem was identified and relevant literature was reviewed. A total of 11 native sheep populated Upazilas of 6 districts were selected purposively. A team of scientists and enumerators were collected the data from respected Upazilas. Table 1 shows the selected Upazilas and respected districts.

Table 1. Selected study areas.

\begin{tabular}{lll}
\hline Sl. No & Name of the District & Name of selected Upazilas \\
\hline 1 & Naogaon & Naogaon Sadar, Mohadevpur \\
2 & Gaibandha & Gaibandha Sadar, Gobindogonj \\
3 & Tangail & Tangail Sadar, Bhuapur \\
4 & Sylhet & Sylhet Sadar, Balagonj \\
5 & Noakhali & Subornochar, Companygonj \\
6 & Bandarban & Nikhongchari \\
\hline
\end{tabular}

\subsection{Development of Interview Schedule}

The interview schedule was developed following the scope of study and rationally. Then the interview schedule was pretested and necessary correction was made. Both quantitative and qualitative data were collected. Some open questions were included for acquiring qualitative data for determining people's estimation and feelings.

\subsection{Estimation of Sample Size for the Survey}

The sheep rearing households were the sample of the research. At first, households were stratified by livestock rearing categories with the help of Upazila Livestock Officer (ULO) of respected Upazilas, and from 10 Upazilas 4 unions and 3 villages from each union were chosen for conducting the survey. However, from Nikhongchari Upazila, data were collected through listed sheep farmers. Therefore, a total of 1768 of sheep rearing households were surveyed using a simple random sampling technique.

\subsection{Data Collection}

Both male and female staffs were involved at the local level for data collection, entry, analysis, and write-up. In order to minimize the level of bias and to improve objectivity, local staff from respective areas was to be assigned to collect data and adequate training was given to the enumerators. Then data was collected through direct faceto-face and on-farm interview. The parameters considered for reproductive performances were as follows: age at $1^{\text {st }}$ heat, age at $1^{\text {st }}$ lambing, litter size, birth weight of lamb.

\subsubsection{Age at $1^{\text {st }}$ Heat or Puberty}

The age at puberty was estimated as the age of the first estrus of the ewe. The sing is wagging tail, swelling, and mucus discharge from the vulva, jumping tendency to others, rubbing their body with the rams and remain closer to the rams [7].

\subsubsection{Age at $1^{\text {st }}$ Lambing}

The age at first lambing was calculated in days from the date of birth to the date of first lambing [7].

\subsubsection{Litter Size}

The litter size was calculated as the numbers of lamb born/conception/ewe.

The litter size was calculated by the following formula:

Litter size (prolificacy)=number of lambs/number of ewes lambing [7].

\subsubsection{Lamb Birth Weight}

The lamb birth weight is the weight of newborns within 24 hours of the birth date. Lamb birth weight was measured by weighing balance and values were recorded in $\mathrm{kg}$ [7].

\subsubsection{Service per Conception Rate}

This is defined as the number of services or insemination required per conception [8].

\subsection{Data Input, Processing, and Analysis}

After completion of data collection, the data were carefully inputted to MS Excel as per output tables. Both the qualitative and quantitative data were summarized and analyzed descriptively using MS Excel and SPSS 20.0.

\section{Results and Discussions}

\subsection{Reproductive Performance of Native Sheep}

Table 1 shows the reproductive traits of native sheep irrespective of study areas. It was examined that the age at $1^{\text {st }}$ heat or puberty was $7.01 \pm 0.03$ months. The highest value was $7.99 \pm 0.01$ month and the lowest was $6.06 \pm 0.01$ month in Gobindogonj and Mohadevpur Upazila respectively. A similar result was found that the age at puberty or first heat 
varied from 5-10 months [7]. The age at $1^{\text {st }}$ lambing was found $12.65 \pm 0.03$ months irrespective of areas and the highest value was $13.91 \pm 0.02$ months found in Gobindogonj Upazila. However, the litter size was found $1.93 \pm 0.01$ similar to $1.85 \pm .02$ [9] and the highest was $2.17 \pm 0.04$ in Balagonj Upazila. Moreover, the average birth weight was $0.94 \pm 0.01$ $\mathrm{kg}$ similar to $0.96 \pm 0.23 \mathrm{~kg}$ [9] and the highest was in Companygonj $(1.76 \pm 0.04 \mathrm{~kg})$ followed by Subornochar $(1.63 \pm 0.18 \mathrm{~kg})$. This is because the productive performance was better for coastal areas [10]. The birth weights of lambs found $1.7 \pm 0.6 \mathrm{~kg}$ and $1.3 \pm 0.1 \mathrm{~kg}$ which was different from the present study may be the different breed and study areas [7]. Furthermore, the service per conception rate was $1.10 \pm 0.01$ and the lowest value was in Gobindogonj $(1.00 \pm 0.01)$. Service per conception rate was found 1.40 to 1.60 [11] which values are slightly higher than the present study.

Table 2. Reproductive performance of native sheep.

\begin{tabular}{|c|c|c|c|c|c|}
\hline Upazila & $\begin{array}{l}\text { Age at } 1^{\text {st }} \text { heat or puberty } \\
\text { (Month) }\end{array}$ & Age at $1^{\text {st }}$ lambing (Month) & Litter size (Nos.) & $\begin{array}{l}\text { Birth weight of } \\
\text { lamb (kg) }\end{array}$ & $\begin{array}{l}\text { Service per } \\
\text { conception rate }\end{array}$ \\
\hline Naogaon sadar & $7.62 \pm 0.13$ & $12.99 \pm 0.15$ & $2.08 \pm 0.02$ & $0.95 \pm 0.02$ & $1.07 \pm 0.02$ \\
\hline Mohadevpur & $6.06 \pm 0.01$ & $12.08 \pm 0.02$ & $1.82 \pm 0.03$ & $0.99 \pm 0.01$ & $1.00 \pm 0.01$ \\
\hline Gaibandha sadar & $6.23 \pm 0.03$ & $11.43 \pm 0.04$ & $1.94 \pm 0.02$ & $0.59 \pm 0.02$ & $1.02 \pm 0.01$ \\
\hline Gobindogonj & $7.99 \pm 0.01$ & $13.91 \pm 0.02$ & $2.00 \pm 0.03$ & $0.98 \pm 0.01$ & $1.00 \pm 0.01$ \\
\hline Tangail sadar & $6.83 \pm 0.08$ & $12.91 \pm 0.15$ & $2.16 \pm 0.05$ & $0.89 \pm 0.01$ & $1.11 \pm 0.03$ \\
\hline Bhuapur & $6.83 \pm 0.06$ & $12.88 \pm 0.07$ & $2.00 \pm 0.05$ & $0.87 \pm 0.01$ & $1.10 \pm 0.02$ \\
\hline Balagonj & $6.45 \pm 0.06$ & $12.49 \pm 0.04$ & $2.17 \pm 0.04$ & $0.98 \pm 0.01$ & $1.09 \pm 0.02$ \\
\hline Subornochar & $7.94 \pm 0.11$ & $12.91 \pm 0.09$ & $1.76 \pm 0.03$ & $0.80 \pm 0.01$ & $1.32 \pm 0.03$ \\
\hline Companygonj & $7.71 \pm 0.16$ & $12.41 \pm 0.17$ & $1.35 \pm 0.06$ & $1.76 \pm 0.04$ & $1.08 \pm 0.03$ \\
\hline Nikhongchari & $7.00 \pm 0.04$ & $12.77 \pm 0.14$ & $1.44 \pm 0.17$ & $1.63 \pm 0.18$ & $1.22 \pm 0.14$ \\
\hline All average & $7.01 \pm 0.03$ & $12.65 \pm 0.03$ & $1.93 \pm 0.01$ & $0.94 \pm 0.01$ & $1.10 \pm 0.01$ \\
\hline
\end{tabular}

Source: Field survey.

\subsection{The Source and Types of Insemination of Native Sheep}

Table 3. The source and types of insemination.

\begin{tabular}{lllll}
\hline \multirow{2}{*}{ Upazila } & \multicolumn{2}{l}{ Source of insemination } & \multicolumn{2}{l}{ Type of insemination } \\
\cline { 2 - 5 } & $\begin{array}{l}\text { Own } \\
\text { ram (\%) }\end{array}$ & $\begin{array}{l}\text { Village } \\
\text { areas (\%) }\end{array}$ & $\begin{array}{l}\text { Natural } \\
(\%)\end{array}$ & $\begin{array}{l}\text { Artificial } \\
\text { (\%) }\end{array}$ \\
\hline Naogaon sadar & 52.97 & 47.03 & 100.00 & 0.00 \\
Mohadevpur & 73.41 & 26.59 & 100.00 & 0.00 \\
Gaibandha sadar & 30.55 & 70.55 & 100.00 & 0.00 \\
Gobindogonj & 96.67 & 3.33 & 100.00 & 0.00 \\
Tangail sadar & 54.96 & 45.04 & 100.00 & 0.00 \\
Bhuapur & 47.26 & 52.74 & 100.00 & 0.00 \\
Sylhet sadar & 40.35 & 59.65 & 100.00 & 0.00 \\
Balagonj & 20.73 & 79.27 & 100.00 & 0.00 \\
Subornochar & 92.59 & 7.41 & 100.00 & 0.00 \\
Companygonj & 95.53 & 4.47 & 100.00 & 0.00 \\
Nikhongchari & 88.89 & 11.11 & 100.00 & 0.00 \\
All average & 60.18 & 39.93 & 100.00 & 0.00 \\
\hline
\end{tabular}

Source: Field survey.

From the study, it was revealed that most of the farmers $(60.18 \%)$ were used own ram for breeding and they used one ram for years. With the utilization of breeding rams within the same flock and less knowledge of sheep keeper, there was a chance for inbreeding found in the irrespective of areas [3]. The highest own ram was found in Gobindogonj (96.67\%) followed by Companygonj (95.53\%) Upazila. However, irrespective of areas $100 \%$ of farmers were used natural breeding practice because there was no Artificial insemination (AI) facility available. A similar result was found in the previous study that most of the farmers (77\%) used their own ram for breeding and all the farmers practiced natural breeding system [12]. The research on artificial insemination (AI) is going on and the preliminary application of frozen semen in the farmer's ewes was conducted. The pregnancy rate was found at a lower percentage [7]. It was recommended that emphasis should be given to introduce AI in ewes using semen from indigenous rams to observe the success of fresh as well as preserved semen [13].

\subsection{Health Management System of Native Sheep}

\subsubsection{Neo-natal Nourishment Practices}

Table 4 shows that the sheep rearing farmers in the study areas were moderately aware of different neo-natal nourishment practices. From Table 4 it was revealed that all farmers in Balagonj, Nikhongchari, and Gaibandha Sadar Upazila were cleaned up mucous after the birth of a lamb. In the irrespective of areas, $67.19 \%$ of farmers were found who cleaned up mucous of lamb after birth. The lowest percentage of cleaned up mucous after birth found in Companygonj $(17.86 \%)$ followed by Subornochar $(21.40 \%)$ Upazila. This is because these two regions were in the coastal areas and the herd size was larger. For this individual care was ignored by the farmers in these coastal areas. However, irrespective of study areas $61.03 \%$ of farmers were cleaned up naval cord after birth. The $100 \%$ farmers in Nikhongchari found cleaned up naval cord after the birth of a lamb. Moreover, the use of antiseptic after cutting of naval cord irrespective of areas was found poor (18.78\%). The highest $63.74 \%$ of farmers found in Sylhet Sadar who used antiseptic after cutting the naval cord. Most of the farmers (92.08\%) fed colostrum after the birth of a lamb. In $97.79 \%$ of cases found that the ewe and lamb reared combined irrespective of study areas. Furthermore, only $19.79 \%$ of farmers have used bedding materials for sheep and among them, $17.19 \%$ of farmers were drying bedding materials in the sun. Table 4 also revealed 
that most of the sheep farmers in different study areas found they didn't dip their sheep and only $6.39 \%$ of farmers were dipping their sheep. Most of the infectious diseases can be prevented through proper management and dipping [14].

Table 4. Neo-natal nourishment of native sheep.

\begin{tabular}{|c|c|c|c|c|c|c|c|c|}
\hline Upazila & $\begin{array}{l}\text { Mucous } \\
\text { clean }(\%)\end{array}$ & $\begin{array}{l}\text { Naval cord } \\
\text { clean }(\%)\end{array}$ & $\begin{array}{l}\text { Antiseptic use in } \\
\text { naval cord (\%) }\end{array}$ & $\begin{array}{l}\text { Colostrum } \\
\text { Fed }(\%) \\
\end{array}$ & $\begin{array}{l}\text { Ewe and lamb } \\
\text { combined (\%) }\end{array}$ & $\begin{array}{l}\text { Bedding } \\
\text { material use (\%) }\end{array}$ & $\begin{array}{l}\text { Bedding materials } \\
\text { clean }(\%)\end{array}$ & $\begin{array}{l}\text { Dipping } \\
(\%)\end{array}$ \\
\hline Naogaon sadar & 77.30 & 98.38 & 30.81 & 95.68 & 100.00 & 20.54 & 18.92 & 21.08 \\
\hline Mohadevpur & 96.03 & 23.01 & 0.00 & 96.43 & 97.22 & 10.32 & 4.37 & 1.98 \\
\hline Gaibandha sadar & 100.00 & 0.00 & 62.22 & 100.00 & 100.00 & 4.44 & 4.44 & 4.44 \\
\hline Gobindogonj & 95.00 & 85.00 & 0.00 & 100.00 & 100.00 & 6.67 & 2.50 & 0.00 \\
\hline Tangail sadar & 74.81 & 70.23 & 10.69 & 67.94 & 89.31 & 27.48 & 22.14 & 13.74 \\
\hline Bhuapur & 31.34 & 94.53 & 0.00 & 100.00 & 100.00 & 9.45 & 4.48 & 20.40 \\
\hline Balagonj & 100.00 & 79.27 & 0.00 & 94.51 & 100.00 & 3.05 & 3.05 & 0.00 \\
\hline Subornochar & 21.40 & 18.11 & 16.46 & 100.00 & 95.06 & 32.92 & 30.86 & 11.52 \\
\hline Companygonj & 17.86 & 0.00 & 0.00 & 100.00 & 100.00 & 5.36 & 3.57 & 2.68 \\
\hline Nikhongchari & 100.00 & 100.00 & 0.00 & 100.00 & 100.00 & 0.00 & 0.00 & 0.00 \\
\hline All average & 67.19 & 61.03 & 18.78 & 92.08 & 97.79 & 19.79 & 17.19 & 6.39 \\
\hline
\end{tabular}

Source: Field survey.

\subsubsection{Anthelmintic and Vaccine Use for Native Sheep}

Table 5 reveals the use of anthelmintic and vaccine for native sheep irrespective of the study areas. It was assessed that $28.51 \%$ of farmers were used anthelmintic and the highest percentage was found in Nikhongchari (100.00\%) followed by Subornochar $(80.65 \%)$ Upazila. In the previous study, it was found that $80 \%$ of farmers practiced deworming sheep regularly which is different from the present study may be for different study areas [2]. The interval of anthelmintic use was practiced mostly 6-month intervals $(13.46 \%)$ followed by a 3-month interval (9.05\%). The deworming has a positive impact on lamb weaning weight
[15]. However, all the farmers were in Nikhongchari Upazila used vaccine, and in Subornochar and Balagonj Upazila farmers were not aware of using vaccines. Only $12.56 \%$ of farmers have used vaccines and among them Peste Des Petits Ruminants (PPR) vaccine was $12.61 \%$. Deworming and vaccination have a positive effect on disease control [14]. Therefore, the anthelmintic and vaccine use status was found poor irrespective of the study areas. Economic loss occurs due to insufficient knowledge and inadequate diagnostic facilities, lack of awareness, and an effective prevention control strategy [16].

Table 5. Anthelmintic and vaccine use.

\begin{tabular}{|c|c|c|c|c|c|c|c|}
\hline \multirow{2}{*}{ Upazila } & \multicolumn{4}{|c|}{ Anthelmintic use } & \multicolumn{3}{|c|}{ Vaccine use } \\
\hline & Yes $(\%)$ & 3 Month (\%) & 4 Month (\%) & 6 Month (\%) & Yes $(\%)$ & P. P. R (\%) & Others (\%) \\
\hline Naogaon sadar & 34.59 & 9.19 & 0.54 & 24.32 & 37.84 & 37.84 & 0.00 \\
\hline Mohadevpur & 12.30 & 5.95 & 5.16 & 1.19 & 9.92 & 9.92 & 0.00 \\
\hline Gaibandha sadar & 2.78 & 1.67 & 0.56 & 0.56 & 3.33 & 3.33 & 0.00 \\
\hline Gobindogonj & 2.50 & 0.00 & 0.00 & 2.50 & 5.00 & 5.00 & 0.00 \\
\hline Tangail sadar & 9.92 & 5.34 & 0.76 & 3.82 & 1.53 & 0.76 & 0.76 \\
\hline Bhuapur & 11.44 & 11.44 & 0.00 & 0.00 & 2.49 & 1.00 & 1.49 \\
\hline Balagonj & 2.44 & 0.00 & 0.00 & 2.44 & 0.00 & 0.00 & 0.00 \\
\hline Subornochar & 80.65 & 0.00 & 16.46 & 64.20 & 0.00 & 0.00 & 0.00 \\
\hline Companygonj & 59.82 & 29.46 & 25.00 & 3.57 & 34.82 & 33.93 & 28.74 \\
\hline Nikhongchari & 100.00 & 0.00 & 0.00 & 100.00 & 100.00 & 100.00 & 0.00 \\
\hline All average & 28.51 & 9.05 & 5.71 & 13.46 & 12.56 & 12.61 & 9.50 \\
\hline
\end{tabular}

Source: Field survey.

\subsubsection{Disease Surveillance of Native Sheep at Field Level}

Table 6 shows the disease surveillance of native sheep at the field level. The responded farmers reported that the native sheep were affected mostly by pneumonia (43.72\%), diarrhea (40.33\%), alopecia $(28.51 \%)$, bloat $(22.79 \%)$, and parasitic infection (15.55\%). However, dog bite $(15.55 \%)$ was found a major problem in native sheep rearing irrespective of the study areas. Moreover, the highest pneumonia (75.67\%) and diarrhea
(88.65\%) reported by farmers in Naogaon Sadar Upazila. The highest alopecia $(64.12 \%)$, bloat $(85.95 \%)$, Peste Des Petits Ruminants (PPR) (30.83\%), parasitic infection (53.51\%), and dog bite $(75.55 \%)$ were reported by farmers in Tangail Sadar, Naogaon Sadar, Gobindogonj, Naogaon Sadar and Gaibandha Sadar respectively. Similarly, the major clinical diseases were determined diarrhea, pneumonia, alopecia, and tapeworm infection in the previous study [14]. 
Table 6. Disease surveillance at field level.

\begin{tabular}{|c|c|c|c|c|c|c|}
\hline Upazila & $\begin{array}{l}\text { Naogaon sadar } \\
(\%)\end{array}$ & $\begin{array}{l}\text { Mohadevpur } \\
(\%)\end{array}$ & $\begin{array}{l}\text { Gaibandha } \\
\text { sadar (\%) }\end{array}$ & $\begin{array}{l}\text { Gobindogonj } \\
(\%)\end{array}$ & $\begin{array}{l}\text { Tangail sadar } \\
(\%)\end{array}$ & Bhuapur (\%) \\
\hline Pneumonia & 75.67 & 64.68 & 8.33 & 3.33 & 51.15 & 44.78 \\
\hline Diarrhea & 88.65 & 12.70 & 17.22 & 32.50 & 64.12 & 23.88 \\
\hline Alopecia & 1.62 & 26.98 & 10.00 & 34.17 & 64.12 & 16.92 \\
\hline Tympani & 0.54 & 2.38 & 5.00 & 0.00 & 0.00 & 0.00 \\
\hline Bloat & 85.95 & 21.03 & 5.55 & 7.50 & 38.93 & 5.47 \\
\hline Peste Des Petits Ruminants (PPR) & 15.10 & 5.95 & 17.77 & 30.83 & 2.29 & 0.50 \\
\hline S. Pox & 0.00 & 1.19 & 0.00 & 0.00 & 0.00 & 0.00 \\
\hline Dog bite & 6.49 & 3.97 & 75.55 & 12.50 & 72.52 & 19.40 \\
\hline Others & 49.73 & 11.50 & 1.11 & 1.67 & 12.21 & 7.96 \\
\hline
\end{tabular}

Table 6. Continued.

\begin{tabular}{|c|c|c|c|c|c|c|}
\hline Upazila & $\begin{array}{l}\text { Sylhet sadar } \\
(\%)\end{array}$ & Balagonj (\%) & $\begin{array}{l}\text { Subornochar } \\
(\%)\end{array}$ & $\begin{array}{l}\text { Companygonj } \\
(\%)\end{array}$ & $\begin{array}{l}\text { Nikhongchari } \\
(\%)\end{array}$ & Overall (\%) \\
\hline Pneumonia & 60.82 & 25.61 & 39.09 & 47.32 & 0.00 & 43.72 \\
\hline Diarrhea & 63.74 & 32.32 & 41.15 & 43.75 & 44.44 & 40.33 \\
\hline Alopecia & 63.74 & 27.44 & 26.34 & 31.25 & 33.33 & 28.51 \\
\hline Tympani & 0.00 & 1.83 & 15.64 & 23.21 & 0.00 & 4.69 \\
\hline Bloat & 50.29 & 6.71 & 2.47 & 4.46 & 22.22 & 22.79 \\
\hline Peste Des Petits Ruminants (PPR) & 1.75 & 6.10 & 10.70 & 15.18 & 0.00 & 9.73 \\
\hline S. Pox & 0.00 & 0.61 & 0.41 & 0.89 & 0.00 & 0.34 \\
\hline Dog bite & 61.99 & 3.04 & 4.12 & 3.57 & 0.00 & 24.43 \\
\hline Others & 20.47 & 7.93 & 0.00 & 0.00 & 22.22 & 11.71 \\
\hline
\end{tabular}

Source: Field survey.

\subsection{Marketing System of Native Sheep}

The marketing of sheep is a very important process in getting a fair price for sheep. Figure 1 shows the mean of sale time weight $(11.12 \mathrm{~kg})$ and age (1.39 years) irrespective of the study areas.

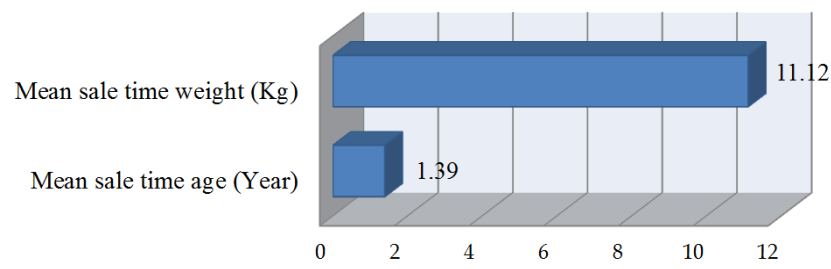

Figure 1. Sale time age and sale time weight of native sheep.
Most of the farmers were sold their sheep in the hat/Bazar $(82.75 \%)$ and only $(11.23 \%)$ on-farm found in the study areas. However, $60.46 \%$ of farmers sell sheep to paiker or bapari followed by the butcher $(22.33 \%)$. Moreover, most of the farmers $(82.28 \%)$ fixed value for the sheep on the basis of eye estimation followed by a weight basis (11.65\%). Furthermore, there was no farmer who sold the wool of sheep irrespective of study areas. From the previous study, it was recommended that the constraints of sheep marketing are lack of market information service, sheep market price fluctuation, lack of market infrastructure, and remoteness of markets. To make improvements in the sheep marketing system, should give more emphasis on research and development activities regarding the marketing of sheep [6].

Table 7. Marketing of native sheep.

\begin{tabular}{|c|c|c|c|c|c|c|c|c|c|}
\hline \multirow[b]{2}{*}{ Upazila } & \multicolumn{2}{|c|}{ Selling place } & \multicolumn{3}{|l|}{ Selling to whom } & \multicolumn{3}{|c|}{ Value fixing (basis) } & \multirow{2}{*}{$\begin{array}{l}\text { Wool } \\
\text { marketing } \\
(\%)\end{array}$} \\
\hline & $\begin{array}{l}\text { Hat/Bazar } \\
(\%)\end{array}$ & $\begin{array}{l}\text { On-farm } \\
(\%)\end{array}$ & $\begin{array}{l}\text { Paiker/Bapari } \\
(\%)\end{array}$ & $\begin{array}{l}\text { Bucher } \\
(\%)\end{array}$ & $\begin{array}{l}\text { Dalal } \\
(\%)\end{array}$ & $\begin{array}{l}\text { Others } \\
(\%)\end{array}$ & $\begin{array}{l}\text { Eye estimation } \\
(\%)\end{array}$ & $\begin{array}{l}\text { Weight } \\
(\%)\end{array}$ & \\
\hline Naogaon sadar & 98.38 & 1.62 & 81.08 & 10.23 & 3.28 & 5.41 & 96.22 & 3.78 & 0.00 \\
\hline Mohadevpur & 89.20 & 10.80 & 73.49 & 12.83 & 4.55 & 9.13 & 82.54 & 17.46 & 0.00 \\
\hline Gaibandha sadar & 98.89 & 1.11 & 76.79 & 15.78 & 6.32 & 1.11 & 96.67 & 3.33 & 0.00 \\
\hline Gobindogonj & 95.00 & 5.00 & 47.53 & 19.27 & 3.47 & 29.71 & 72.5 & 27.50 & 0.00 \\
\hline Tangail sadar & 93.89 & 6.11 & 57.73 & 25.60 & 5.98 & 10.69 & 94.66 & 5.34 & 0.00 \\
\hline Sylhet sadar & 95.91 & 4.09 & 51.30 & 31.98 & 12.63 & 4.09 & 87.71 & 12.28 & 0.00 \\
\hline Balagonj & 96.34 & 3.66 & 53.11 & 22.77 & 19.85 & 4.27 & 58.54 & 41.46 & 0.00 \\
\hline Subornochar & 75.30 & 24.70 & 36.17 & 55.78 & 3.11 & 4.94 & 92.59 & 7.41 & 0.00 \\
\hline Companygonj & 86.61 & 13.9 & 54.54 & 37.87 & 4.91 & 2.68 & 92.86 & 7.14 & 0.00 \\
\hline Nikhongchari & 0.00 & 33.33 & 55.37 & 4.5 & 6.80 & 33.33 & 33.33 & 0.00 & 0.00 \\
\hline All average & 82.75 & 11.23 & 60.46 & 22.33 & 7.21 & 6.96 & 82.28 & 11.65 & 0.00 \\
\hline
\end{tabular}

Source: Field survey. 


\section{Conclusion}

From the study, it may be concluded that the reproductive performance of native sheep was found good irrespective of the study areas. All the native sheep farmers were used natural breeding practice. The sheep rearing farmers in the study areas were found moderately aware of different neo-natal nourishment practices. The native sheep mostly affected by pneumonia, diarrhea, alopecia, bloat, and parasitic infection found in the study areas. However, the dog bite was found a major problem in native sheep rearing irrespective of the study areas. The use of anthelmintic and vaccine was found poor irrespective of the areas. Moreover, the marketing system of native sheep was found also very poor. Lack of organized and structured marketing system found in the study areas. Emphasize should be given to the sustainable improvement of reproductive and health management of native sheep and marketing systems to improve the livelihoods of rural poor farmers in the context of Bangladesh.

\section{Conflict of Interest}

The authors declare that they have no competing interests.

\section{Acknowledgements}

"Conservation and improvement of native sheep through community and commercial farming" (Component-A, Research 2nd phase), Bangladesh Livestock Research Institute, Savar, Dhaka, Bangladesh, has provided technical and financial support.

\section{References}

[1] Ahmed S., Rakib M. R. H., Yesmin M., Sultana N., Jahan N. and Ershaduzamman M. (2018). Evaluation of lamb production potentiality of the Barind, Jamuna river basin and coastal region sheep of Bangladesh under intensive management. Journal of Advanced Veterinary and Animal Research. 5 (1): 37-43.

[2] Hossain M. A., Islam M. A., Akhtar A., Islam M. S. and Rahman M. F. (2018). Socio-economic status of sheep farmers and the management practices of sheep at Gafargaon upazila of Mymensingh district. International Journal of Natural and Social Sciences. 5 (4): 07-15.

[3] Getachew T., Haile A., Tibbo M., Sharma A. K., Sölkner J. and Wurzinger M. (2010). Herd management and breeding practices of sheep owners in a mixed crop-livestock and a pastoral system of Ethiopia. African Journal of Agricultural Research. Vol. 5 (8), pp. 685-691.

[4] Islam S., Khatun M., Ershaduzzaman M., Khan M. A., and Yasmin S. (2018). Climate change, livestock production and income vulnerability- Bangladesh perspective. African Journal of Economics and Sustainable Development. 1 (1) pp. 1-12.
[5] Victor H. Suárez and Margarita R. Busetti. (2009). Health management practices and disease prevalence indairy sheep systems in Argentina. Pesq. Vet. Bras. 29 (11): 931-937.

[6] Abebe, Y., Melaku, S. and Tegegne, A. (2013). Assessment of sheep marketing system in Burie district, North Western Ethiopia. Wudpecker Journal of Agricultural Research. 2 (3): 97-102.

[7] Mansur M. A. A., Alam M. G. S., Kumar Jha P., Rimon M. A., Naher N. and Bari F. Y. (2018). Productiveand reproductive performances of Sheep at field level of Rajshahi and Mymensingh District of Bangladesh. Asian J. Med. Biol. Res. 4 (1), 63-68; doi: 10.3329/ajmbr.v4i1.36823.

[8] Habib M. A., Bhuiyan A. K. F. H. and Amin M. R. (2010). Reproductive performance of Red Chittagong Cattle in a nucleus herd. Bang. J. Anim. Sci., 39 (1\&2): 9-19.

[9] Sarder M. J. U., Islam M. H., Moni M. I. Z., Jahan S. S., Aktar S. and Uddin J. (2015). Reproductive and productive performance of sheep of Rajshahi, Bangladesh insight about effects of genotype and parity. Bangladesh livestock journal. $1: 31-34$.

[10] Hassan M. R. and Talukder M. A. I. (2011). Comparative performance of different regional native sheep in Bangladesh. The Bangladesh Veterinarian. 28 (2): 85-94.

[11] Sultana N., Hasan M. N., Iqbal A., Ershaduzzaman M., Talukdar M. A. I., and Dey S. (2011). Effect of Intensive and Semi-intensive Feeding System on Productive and Reproductive Performances of Native Sheep. J. Sci. Res. 3 (3), 693-698.

[12] Hossain M. A., Akhtar A., Easin M., Maleque M. A., Rahman M. F., Islam M. S. (2018). Women livelihood improvement through sheep (Ovis aries) rearing in Sirajganj district of Bangladesh. International Journal of Natural and Social Sciences. 5 (3): 01-08.

[13] Azizunnesa, Zohara B. F., Bari F. Y. and Alam M. G. S. (2014). Baseline Study of Reproductive Performances of Indigenous Rams in Bangladesh. Journal of Agriculture and Veterinary Science. 7 (6): 83-89.

[14] Munsi M. N., Ershaduzzaman M., Rahman M. M. and Rahman M. M. (2016). Incidence of clinical diseases and disorders in native sheep at the sheep research farm of Bangladesh Livestock Research Institute, Savar, Dhaka, Bangladesh from 2012 to 2014. Asian Australas. J. Biosci. Biotechnol. 1 (1): 37-46.

[15] Martínez M. E., Calderón C., Uribe H. and de la Barra R. (2012). Effect of management practices in the productive performance of three sheep breeds in the Chiloé Archipelago, Chile. J. Livestock Sci. 3: 57-66.

[16] Ahmed B. S., Osmani M. G., Rahman A. K. M. A., Hasan M. M., Maruf A. A., Karim M. F., Karim S. M. A., Asaduduzzaman M., Hasan M. R., M. Rahman M., Rahman M. S. (2018). Economic impact of caprine and ovine brucellosis in Mymensingh district, Bangladesh. Bangl. J. Vet. Med. 16 (2): 193-203. 